\title{
Readiness and Acceptance in Using Web- Community for Developing CPD Among Teachers of Remote Areas in Central Kalimantan
}

\author{
${ }^{1 s t}$ Elanneri Karani \\ Faculty of Teacher Training and Education \\ Universitas of Palangka Raya \\ Palangka Raya, Indonesia \\ elannerikarani@gmail.com
}

\author{
${ }^{2 n d}$ Dehen \\ Faculty of Teacher Training and Education \\ Universitas of Palangka Raya \\ Palangka Raya, Indonesia
}

\begin{abstract}
The study explores the readiness and acceptance in using the cloud-based community as a platform for continuous professional development (CPD) among teachers of remote areas from thirteen regencies in Central Kalimantan. The survey involves one hundred fifty teachers of English and Social Science who joined the Teachers' Certification Program 2017, organized by the Ministry of Education and Culture of the Republic of Indonesia in collaboration with the University of Malang (UM) and the University of Palangka Raya (UPR).This group of teachers respond to the questionnaire consisting ten items as a reflection of the readiness and acceptance in using Web-Community for developing CPD. Descriptive analysis with the percentage was done to reveal the level of readiness and acceptance in using web-community among this group. The results reveal, despite the fact that the low and the lack of internet access in isolated areas is the significant point causes the cloud-based communication runs unwell, however all respondents are receptive towards Webcommunity. In addition, the web applications they use most frequently to communicate for developing CPD are WhatsApp, Facebook, and E-mail. This indicates that the teachers of English and Social Science of remote areas of Central Kalimantan are ready to develop the CPD using the cloudbased communication.
\end{abstract}

Keywords - acceptance and readiness, web-community, teachers of English and Social Science, remote areas

\section{INTRODUCTION}

In the long run of the teacher certification in Indonesia that has been carried out since 2006, there are remaining a hundred-thousand and more the teachers of remote areas who are working hard to get the certification licensure. From year to year this group of teachers keep on upgrading their competences and abilities to meet the criteria of professional teachers as demanded by the Teacher Law to improve the teachers' quality. This is important to be done since the demand and challenges in the field of teaching also changing.

In context of the field of teaching, the teachers in Indonesia are categorized into two groups in accordance with schools' location. First group is the teachers who are teaching in cities and towns and the second one, those who are working in very small towns and villages that are far away from cities and towns. The last group are living at remote areas at which the facilities such as electric power and clean water are expensive to get and pay. For example, there are small villages of Pulau Malan Disctric of Katingan Regency and Tanah Siang District of Murung Regency. These two villages are located near the border of two provinces, namely the Central Kalimantan Province and the West Kalimantan Province. The teachers spend at least two days to get to Palangka Raya the capital of Central Kalimantan province. In the first day, they have to take the trip by the local transportation: a small motor boat, they called: $C E S$ to get to the capital of regency called Kabupaten. In the next day, from the capital of the regency, they continue the trip by a bus or a car. It takes 4-13 hours to get to Palangka Raya (the capital of Central Kalimantan province) a place where the teacher certification program is conducted year by year [8]. So, the teachers in such a remote areas challenge different things than those who stay and teach in towns such as: Palangka Raya and Sampit. As teachers of the $21^{\text {st }}$ Century, in the daily life, they have to compete and struggle under such a condition, whether the conditions where they stay are comfortable or uncomfortable to support them to do their job, however, it is a must for them to do the duties as teachers with the label 'the teachers of remote areas. They have to feel at ease when it is hard for them to get internet access, even to get in touch for communication via smartphone if they have due to the lack of electric power and unreachable signal of TELKOMSEL. However, one of the most challenging duties they have to compete is to pass the teacher certification program via the online testing of UKG for getting the label of an Indonesian professional teacher as mandated by The Teacher Law [6]; [10]; [13]; [15].

\section{A. The Activities Reflection towards the Teacher Certification Program 2017}

Last year, in 2017, the University of Palangka Raya (UPR) under the supervision of the State University of Malang (UM) carried out the teacher certification as a regular program to assist the teachers from many towns and small villages in the area of the Central Kalimantan 
provinces to prepare themselves for online-testing of Uji Kompetensi Guru Nasional. There are more than nine hundreds (900) teachers from different places came and joined the program that took place in Palangka Raya.The teachers who attended this program have different major of study, for example English, Social Science, Mathematics, Biology and so on. The program spent three periods of time due to the a big number of participants who attend the main meeting, and this project was conducted in two sessions where the teacher joined in two meetings, namely PraKondisi activity and Program Pelatihan Guru (PPG) activity.

There are some activities done by the teachers during 'Pra-Kondisi' session as follows. First they have to activate a personal account via cyber link using the internet access. Then, they have to download modules as instructional materials they need doing independent study. Next, they have to complete the given tasks based on the prepared modules by answering the exercises provided in each series of module. While doing the tasks, the teachers are asked to get in touch via what is called as Teachers' Forum online access. This link connects a teacher to a tutor and her/his classmates individually or in group to discuss and communicate the contents and the exercises of prepared in the modules. The link is helpful for the teachers to clarify the unclear materials in the modules with the tutor or asked her/his classmates' helps to complete the tasks in the modules. So, the teachers make use this link as arena to share, take and give among others, in the case of upgrading and improving both their knowledge and skills to become professional teachers in the future. At least, they are able to pass the online testing program of Uji Kompetensi Guru Nasional (UKG), and get the passing grade as the minimum standard of criteria of an Indonesian professional teacher who will get incentive as reward for their competence [8]; [10]. Having a label of the teachers of remote areas, year by year they are still very enthusiastic to join the teacher certification program.

The online testing of UKG is a process to select teachers of all over Indonesia from different background to compete for getting the label as an Indonesian professional teacher. Consequently, the teachers of remote areas have to work harder than those from cities and towns. Thus, it is reasonable if this group has less chance to pass the online testing of UKG. This happens due to the lack of electric power and the poor internet connection.

On the other hands, the experiences when attending the teacher certification program lead them to be aware of the importance of developing and managing communication among the community which has earned the label as professional teachers. So this paper proposes a question as follows: Are the teachers ready and do they accept to use web-community for developing CPD among teachers of remote areas, specifically in Central Kalimantan region?

\section{B. Web-Community to develop CPD among Teachers}

Central Kalimantan province has 1.5 wider than Java Island a whole. It means the Central Kalimantan province is larger than Java's island. This area separates into thirteen Districts and one Municipality. There three districts are nearer to the boarder of the Central Kalimantan province and West Kalimantan province, namely, Katingan Hulu
District, Kecamatan Kahayan District, and Laung Tuhup District. People in these areas are used to using smartphone for long distance communication. In daily activity, they are familiar to operate WA, FB, E-mail, and other internet applications. The teachers who stay in these areas are either doing the same thing. This is in line with the research findings that report the use of social media in South Asia has been growing steadily over the last decade [2]. The digital empowerment leads not only common people but also teachers to get closer and easier to get in touch to each other by using web-applications [11]; [6]; [14]. This is possible because the infrastructure such as the availability of electric power is available significantly. So, it is no matter how far away the schools location from cities since the electric power works very well, the cyber link is still working well either.

In contrast, there many small villages in some districts called Kecamatan in Central Kalimantan province that has insufficient electric power to link to internet connection. The teachers in these areas face difficulty to operate internet connection at school time. This condition leads the teachers ineffectively to demonstrate their practical skill using internet applications such downloaded research reports from the online journal system and other practical teaching program websites [4]; [13]; [18]. At which those activities are very useful to assist the teachers develop their abilities and improve the teaching quality in school time. The lack of infrastructure availability can affect the teacher performances in terms of showing their professional competence such doing academic publication, for example.

However, the Teachers Law mandates the teachers from all over Indonesian regions to behave and perform as professional teachers who are able to do professional activities, such as upgrade their knowledge and teaching skills regularly by conducting and reporting CARs, doing academic publication by writing scientific articles, attending national and or International Conference by having oral presentation, and so on. These professional activities are possible to be done if they actively involved in the communication linkage that occur among the professional community, teachers' web-community, for example.

In relation to the fact that a professional teacher in Indonesian context should refer their professional activities to the competencies stated in the Teacher's Law, therefore, this paper reports how teachers of remotes areas perceive this phenomena from their point of view about the possibility to create and manage the teachers' webcommunity to assist them in developing CPD continuously. So, the research objective is to report the readiness and acceptance in using web-community for developing CPD among the teachers of remote areas of Central Kalimantan.

\section{METHOD}

This need analysis study is done by collecting the teachers of remote areas' opinions of the readiness and the acceptance in using web-community for developing CPD by using questionnaire with for optional answers, namely: a) strongly agree, b) agree, c) least agree, and d) disagree. The questionnaire consists of ten items describing the teachers of remote areas' perceptions of their readiness and acceptance in using web-community for developing CPD. Their responses on the given questions are calculated to get 
percentages describing the respondents' tendency. The lowest percentage is to indicate the least negative response, while the highest percentage is to show the most positive responses. One hundred questionnaires were distributed to one hundred of the teachers of remote areas who responded to the given questionnaire.

\section{FINDINGS AND DISCUSSION}

These research findings are distinguished into the following remarks: 1) the perceptions of the teachers of remote areas in using the web-community for developing CPD, and 2) the use of computers (laptops, Pcs, and tablets), and social media they are familiar to operate.

First, the perceptions of the teachers of remote areas in using the web-community for developing CPD indicate that $100 \%$ of the respondents strongly agree for developing CPD through this project (see Table 1). They also stated (76\% of respondents) that the limited stock of electric power can be manipulated by adapting the schedule of using webcommunity connection starts from 6-9 every night (see Table II). Second, all respondents claimed they use social media as a means for the cloud communication: WA, FB and e-mail, and able to make use these tools for developing CPD (see Table 3). In detail, it can be read in the following tables below:

1. TABLE I. THE PERCEPTIONS OF THE TEACHERS OF REMOTE AREAS IN USING WEBCOMMUNITY FOR DEVELOPING CPD

\begin{tabular}{|c|c|}
\hline Optional Answer & Percentage (\%) \\
\hline Strongly agree & 100 \\
\hline
\end{tabular}

TABLE 2. USING WEB-COMMUNITY CONNECTION STARTS FROM 6-9 EVERY NIGHT FOR MANIPULATING THE LIMITED STOCK OF ELECTRIC POWER

\begin{tabular}{|c|c|}
\hline Optional answers & Percentage (\%) \\
\hline Agree & 76 \\
\hline
\end{tabular}

TABLE 3. USING SOCIAL MEDIA AS A MEANS FOR THE CLOUD COMMUNICATION: WA, FB, AND EMAIL

\begin{tabular}{|c|c|}
\hline Optional answers & Percentage (\%) \\
\hline Strongly agree & 100 \\
\hline
\end{tabular}

The research findings revealed that most of the teachers of remote areas are able to involve in communication in the cloud by cyber link connection. This finding is supported by the previous research showed that in the South Asian countries teachers are familiar to operate computers, laptop, and other social media tools as well, but they need some helps from expert to maximize the access, and opportunities to use them for developing CPD [2]; [18]; [5]; [10] This also means that the $21^{\text {th }}$ teachers are not only in capable to use hand phone but also skilful to operate other social media for communication among their colleagues. They make use social media to develop the collaborative working between the teachers in cities and the teachers of remote areas. This finding pinpoints that the need of communication for professional purposes via webcommunity is needed badly for designing a CPD development for the teachers of remote areas, specifically for solving the problem occurs in Central Kalimantan. This project is possible to develop by involving other teaching experts and well-experienced teachers who can give advises and assistance for running the program well.

\section{CONCLUSION AND FUTURE WORK}

The teachers of remote areas have the responsibility to perform and manage their duties to become professional teachers as mandated by the Teacher Law. However, it is the fact, they stay at remote areas, the lack of infrastructure may lead them to be ineffective professional teachers if no one cares of them. In this case, the helps from others colleagues who stay in cities and have more sophisticated knowledge and teaching skills are very useful for them developing their teaching competence and quality as well. So, the idea designs a web-community in order to hand in hand for developing CPD among the teachers of remote areas is badly needed.

\section{REFERENCES}

[1] A. D. Katuuk, and L.K.M. Marentek, "Indonesian primary school teacher's perception of professional development programs: A case study," International Journal of Education and Research, vol.2, No. 6, June 2014, pp. 629-634.

[2] A. Rahman, "Teacher professional development in Indonesia: The influences of learning activities, teacher characteristics and school conditions". Doctor of Philosophy Thesis. University of Wollongong, 2016. Research Online: http://ro.uow.edu.au/theses/4721

[3] B. Rahman, et.al., "Teacher-based scaffolding as a teacher professional development program in Indonesia," Australian Journal of Teacher Education, vol. 40, Issue 11, Article 4, pp. 67-78, 2015.

[4] British Council Team, "Technology for professional development: access, interest and opportunity for teachers' of English in South Asia," Research Report, 2015. www.britishcouncil.org

[5] C. D. S. Indrawati and D. Octoria, "Continuous professional development to improve the teachers' competencies," Proceeding The $2^{\text {nd }}$ International Conference on Teacher Training and Education, UNS, vol.2, No. 2, 2016, pp. 656-663, 2016.

[6] D. P. D. Putri Adnyani, "Professional development for pre-service teacher: A case study of professional development for pre-service teacher in State University in Central Indonesia," Master Thesis of International and Comparative Education, Stockholm Universitet, 2015 .

[7] E. Karani, "The performances of the certified nglish teachers in municipality of Palangka Raya, Central Kalimantan," Dissertation, English Education of Postgraduate Program of The State University of Malang, 2013.

[8] H. A. Nugroho, "Model of language competence upgrading program for English teachers in Indonesia," Advances in Social Science Education and Humanities Research (ASSEHR), vol. 108, Social Science, Humanities and Economics Conference (SoSHEC 2017), pp. 264-267.

[9] H. Tanang and B. Abu, "Teacher professionalism and professional development practices in South Sulawesi, Indonesia," Journal of Curriculum and Teaching, vol. 3, No.2, 2014, pp. 25-42.

[10] H. Waheed et.al., "Collaborative web-based teacher professional development system: A new direction for teacher professional development in Malaysia," International Journal of Humanities and Social Science, vol. 1, No.7, pp.208-216, June 2011.

[11] I. K. Yusri, and R. Goodwin, "Mobile learning for ICT training: enhancing ICT skill of teachers in Indonesia," International Journal of e-Education, e-Bussiness, e-Management and e-Learning, vol. 3, No. 4, pp. 293-296, August 2013.

[12] I. Syahril, "The Indonesian teacher certification policy: a case study of policy sense-making," A Dissertation of Doctor Philoshophy of Curriculum, Instruction and Teacher Education, Michigan State University, 2016.

https://d.lib.msu.edu/.../The_Indonesia_Teacher_Certification_Policy A Case Study

[13] M. H. Bin Haris Fadhilah et.al., "G+ community: Measuring teachers' readiness and acceptance," EduLite Journal, vol.2, No.2, pp.361-376, August 2017. 
[14] M. Fahni, et.al., "Teacher certification in Indonesia: a confusion and means and ends," Working Paper in Economics and Development Studies, Department of Economics Padjajaran University, July 2011. http://econpapers.repec.org/paper/unpwpaper/

[15] N. Fauziyah and S. Uchtiawati, "Developing a model of educators" professional training special for remote areas through the implementation of lesson study," International Education Studies, vol. 10, No.8, pp. 108-115, 2017.

[16] P.N. Kusumawardhani, "Does teacher certification program lead to better quality teachers? Evidence from Indonesia," Education Economics, vol. 25, No. 6, Routledge: Taylor and Francis Group, 2017, pp. 590-618.

[17] R.A. Razak and F.D. Yusop, "Designing framework of electronic continued professional development for teachers (e-CPD)," Paper Presented at the Annual International Conference on Management and Technology in Knowledge, Service, Tourisme \& Hospitality, Jakarta, Indonesia, 2013.

http://umexpert.um.edu.my/file/publication/00006651 1022227.pdf

[18] T.S. Ming et.al., "Supporting smart school teachers' continuing professional development in and through ICT: A model for change," International Journal of Education and Development using Information and Communication Technology (IJEDICT), vol. 6, Issue 2, pp. 5-20, 2010 